児童のテレビ行動におけるオピニオン・リーダーシップ

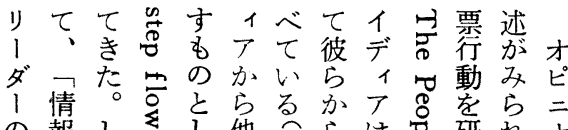

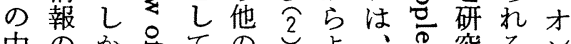

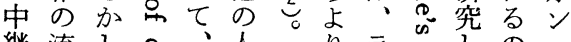
継流し8 人, ラ。しの・

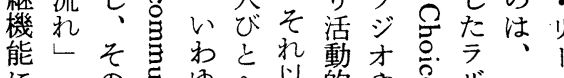

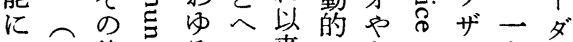
つ㤩後るの来で印に1 九 1 問 児 童

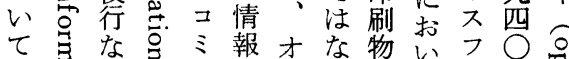
は怘わこニの次いか物い年す 多豆れに二中二人らでルの方

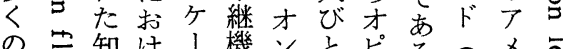

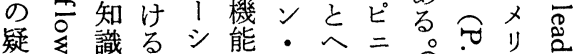

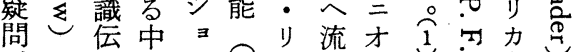
がに播心ン怘! れン彼穴大 も打要の串る・市統に たけ関素段は1こリ注領つ

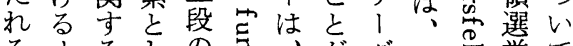
るオるしのう、がダそ气挙て よピ 研て流壱、多、它ににの $う 二$ 究考机导不へ中ら撮 に才にえな、虫にけ初

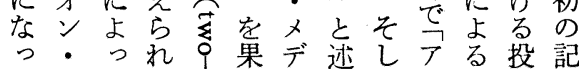

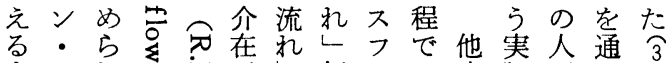

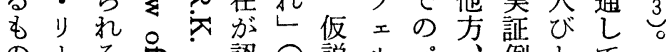
の 1 る。認手説ルパ、例とて とダ

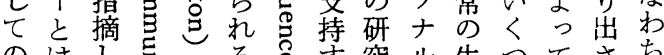
のはし吉注宁究ル生つてさち 助、て高と心るでな活かされ

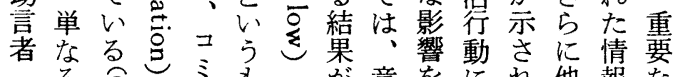
る

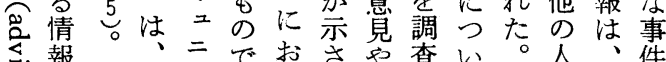
報か影尔でおさや查い。人、件 ののか影ケあいれ行してび直に ○中品響りるてて動た、接つ

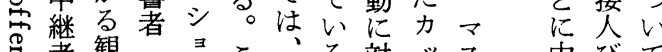

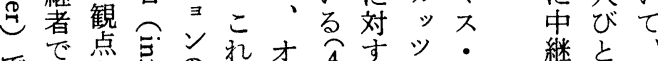

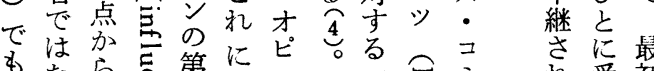

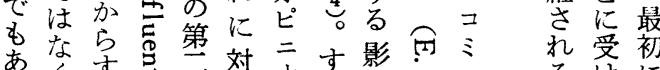

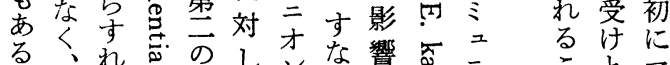

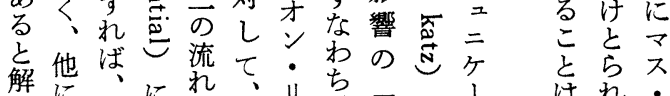

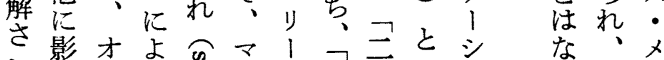

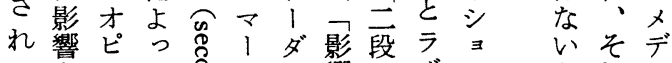

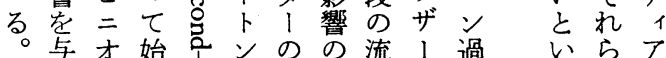


のいれオ析

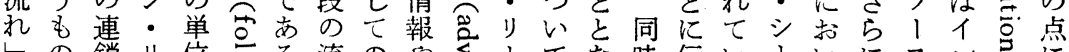

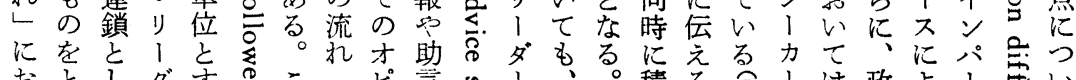

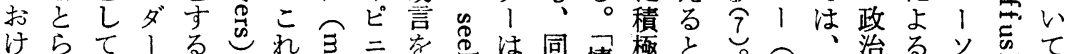
るちえて

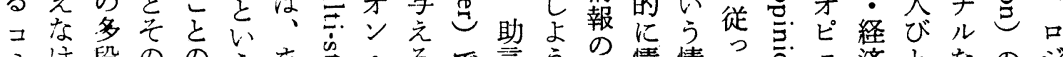

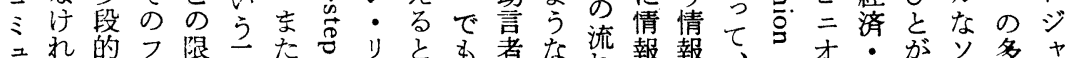
二れ的フ限三たすりとも者な流報報、的才がソ多ャ

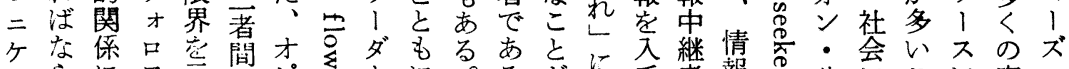

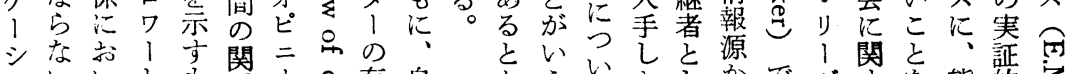

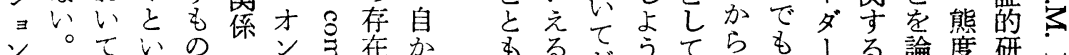

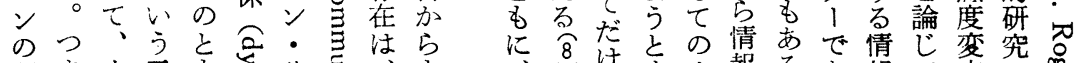

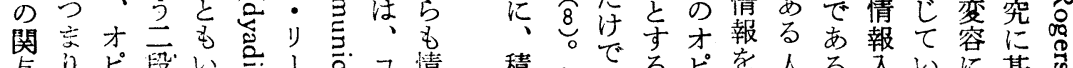

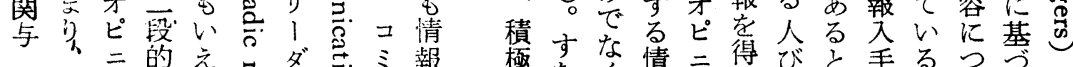

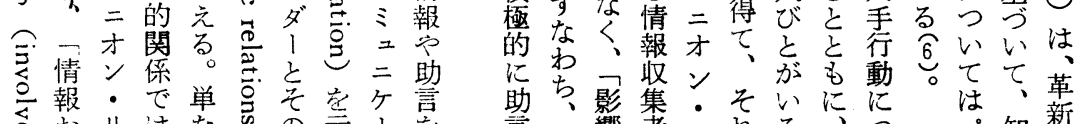

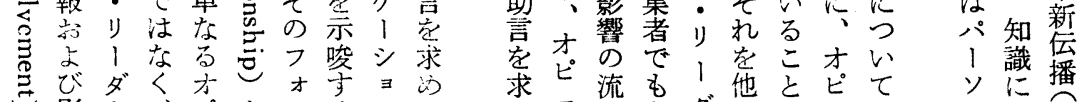

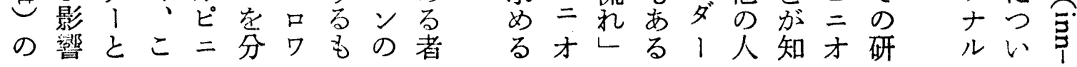

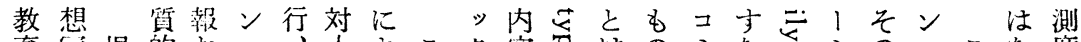
育定监的お・置閏よこク容邑はのミなさシのへこな度

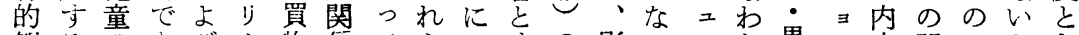

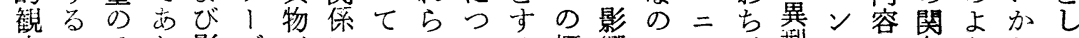
点こテり影ダ、に二のいる概響かケ、型のの省のうとて

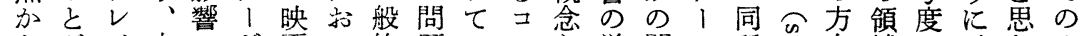
らがビ内のが画い的題のミと単問シ質芯向域と施才

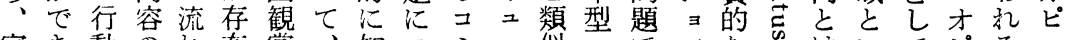

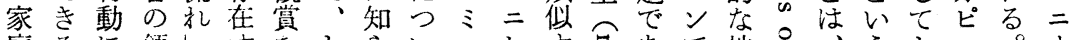

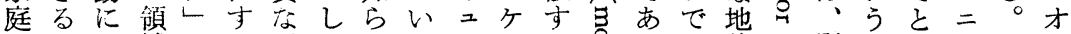

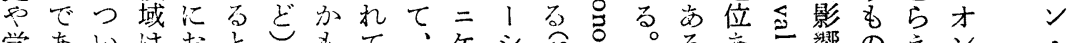

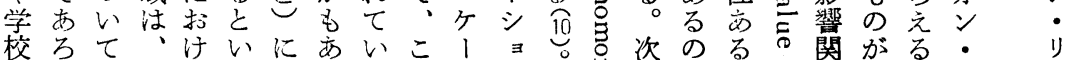

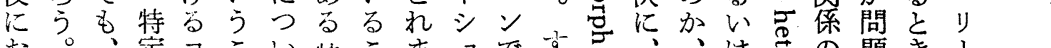

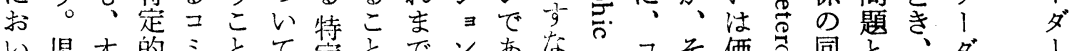

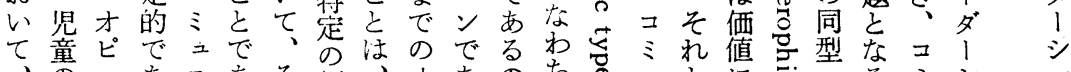

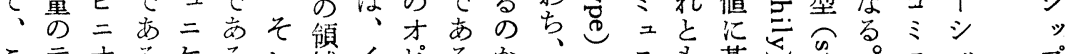

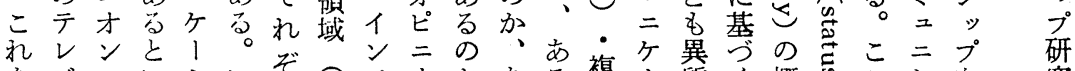

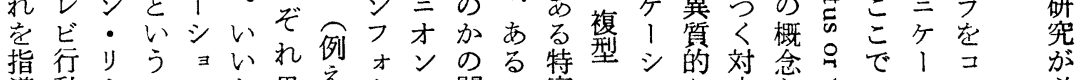

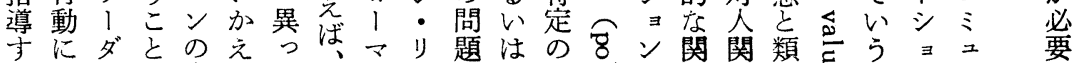

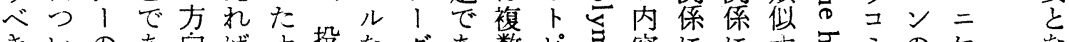

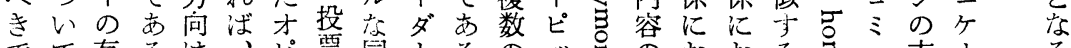

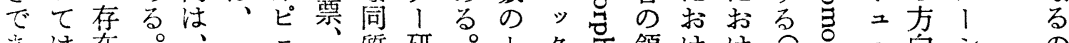

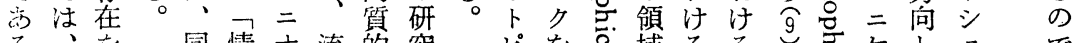
る、同情才流的究 ピ老域るる 
児童のテレビ行動におけるオピニオン・リーダーシップ

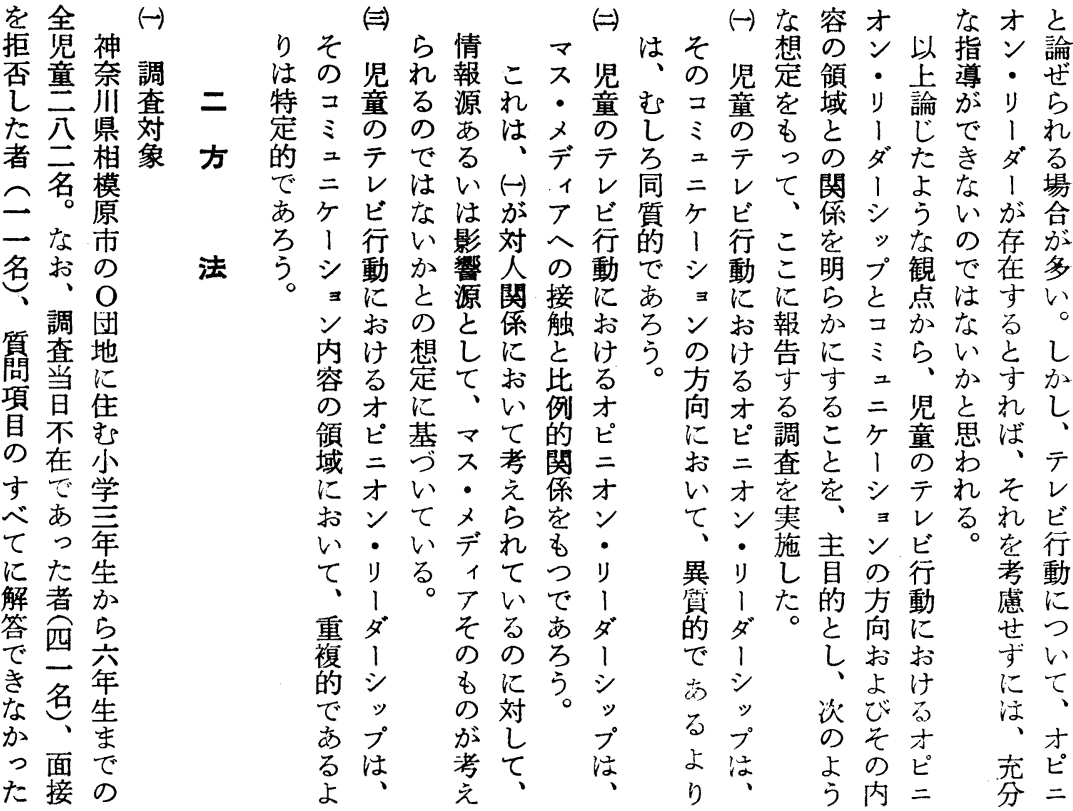

ダ与反適し関情討妥尺はにこなのオ

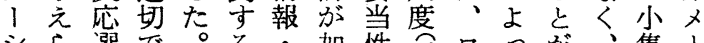
シ 選で。る・加性质口名、集卜 ッ根な四四助充お活たでか団り プる肢い項項言らよな+。きつでッ

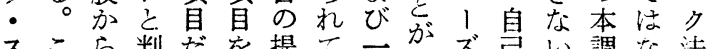

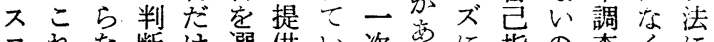
コれな断け選供い恣るる暒の查くに

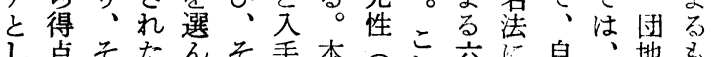

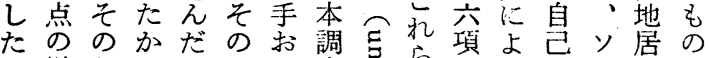

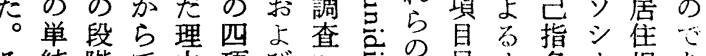

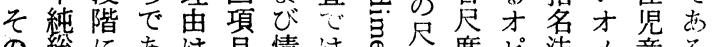

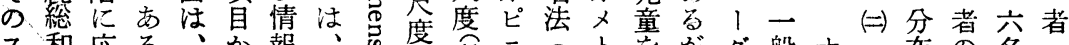

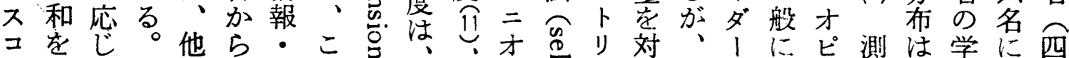

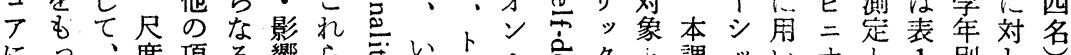

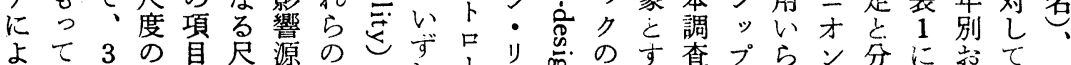

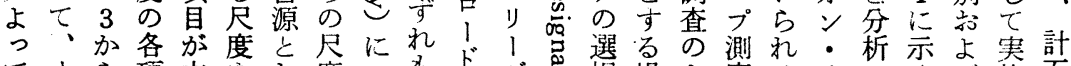

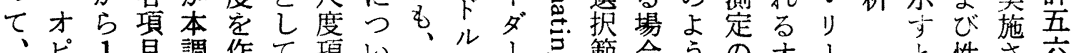

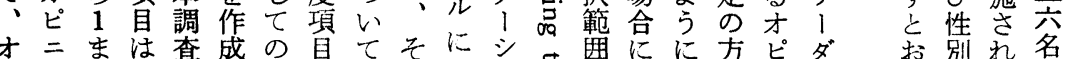

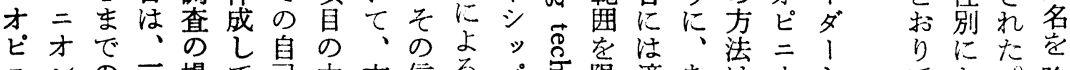

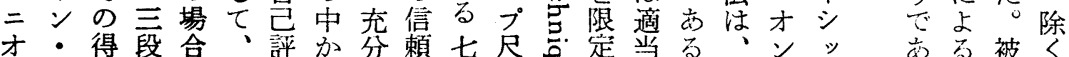

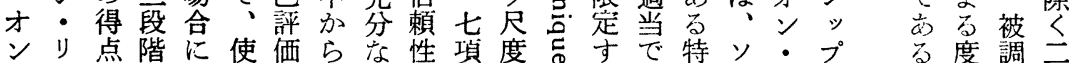

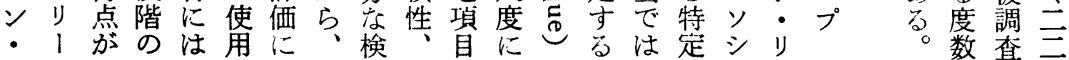




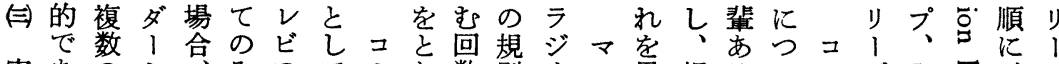

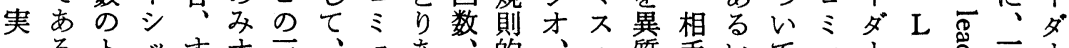
るトッすオ三、ニあ、的、・質手いて

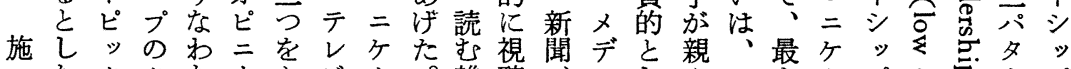

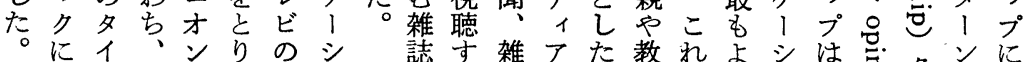

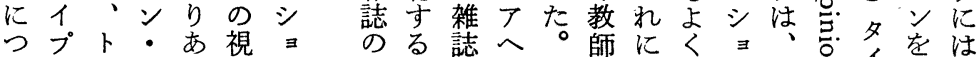

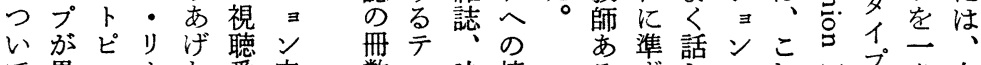
て異ッ1た番内数レ映接るずしのれたプ、九 同なクダ。組容、ビ画触いる合方 5 另 $\mathrm{M}$ 亿

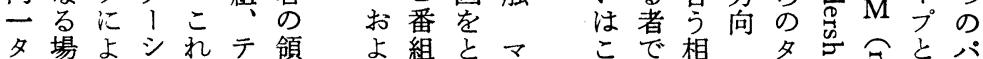

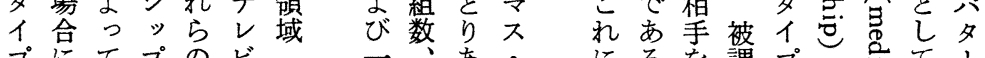
プにてプのビー我あるを調プ に、、のト・テ学ラげメ、準場自查にタ志、!

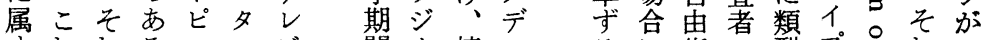
寸れれるッレビ間オ接 1 るに指に型プすれで るをぞークン行の聴触フ者は名、花と志ぞき 場特れつのト動劇取量と艺さあさしするずる 合定オのう、に場のとしてるるれた。る゙

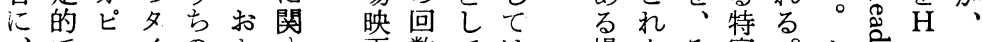

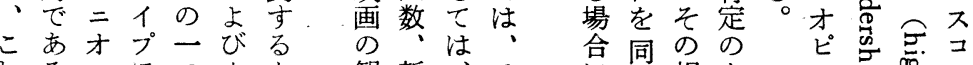

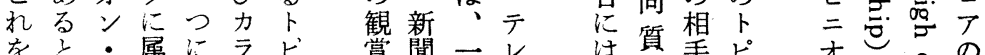

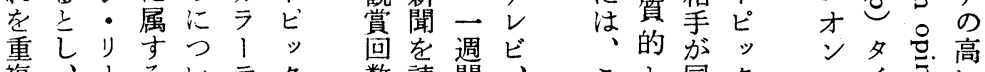
複、1るいテク数読間、を同ク・イきい

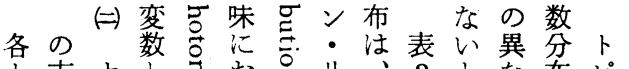

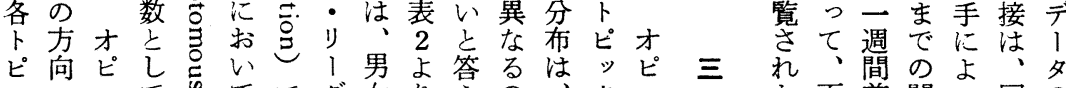

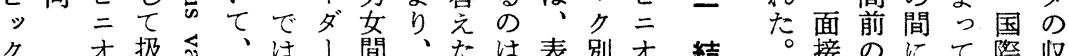

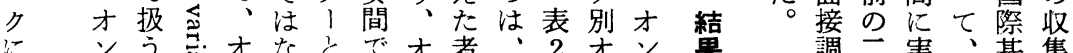
にンうこオなとでオ者・2オン果調三実、基集

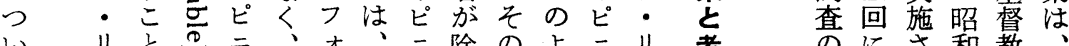

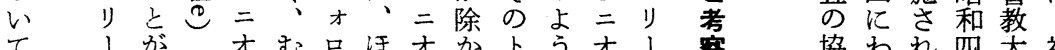

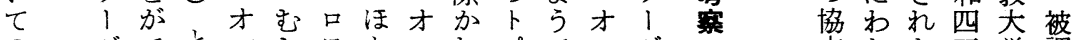
のダでとンしワとンれた゚でンダンガたた吾学調

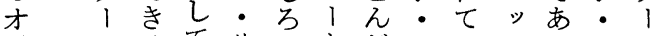
ピ シるてリ正とどリいクつリシ ニッとで、嫢い差、るにたはッ オプいはダ分っがダたつ。ダプ ン・えな、布たな、めいト1の ・ タるくシに双いシでてピシタ

リイで、近峰しッあ、ッッイ

1プああプい性プる誰クププ ダとろるはこ分分・管に・

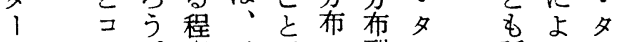

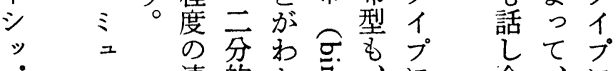

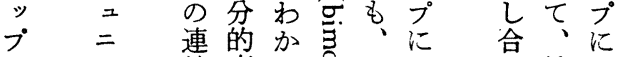

- ケ続変る。才吕才つ被つ

夕 1 性数。比いた調い

プ シ 记。年視 查 つ実至聴者 い・施月覚の 七団に七教自 の地あ・䏍宅 依子た八研に 頼どっ日究お 書むての窒け が会は両にる 各を、日関個 被通そ、係別 調じの午す面 查、一後 る 接 者同力一学に の会月時生よ 家の前か沶っ 庭名おらよた 
児童のテレビ行動におけるオピニオン・リーダーシップ

表 2 オピニオン・リーダーシップ・タイプの度数分布

\begin{tabular}{|c|c|c|c|c|c|c|c|c|c|}
\hline \multirow{2}{*}{ タイプ } & \multicolumn{3}{|c|}{ テレビ番 組 } & \multicolumn{3}{|c|}{ テレビ・タレント } & \multicolumn{3}{|c|}{ カラーテレビ } \\
\hline & 男 & 女 & 計 & 男 & 女 & 計 & 男 & 女 & 計 \\
\hline $\mathrm{H}$ & $\begin{array}{r}22 \\
(21)\end{array}$ & $\begin{array}{r}28 \\
(28)\end{array}$ & $\begin{array}{r}50 \\
(25)\end{array}$ & $\begin{array}{r}16 \\
(23)\end{array}$ & $\begin{array}{r}22 \\
(32)\end{array}$ & $\begin{array}{r}38 \\
(27)\end{array}$ & $\begin{array}{r}14 \\
(23)\end{array}$ & $\begin{array}{r}12 \\
(26)\end{array}$ & $\begin{array}{r}26 \\
(25)\end{array}$ \\
\hline & $\begin{array}{r}57 \\
(54)\end{array}$ & $\begin{array}{r}46 \\
(47)\end{array}$ & $\begin{array}{r}103 \\
(50)\end{array}$ & $\begin{array}{r}32 \\
(46)\end{array}$ & $\begin{array}{r}30 \\
(43)\end{array}$ & $\begin{array}{r}62 \\
(45)\end{array}$ & $\begin{array}{r}36 \\
(60)\end{array}$ & $\begin{array}{r}22 \\
(48)\end{array}$ & $\begin{array}{r}58 \\
(55)\end{array}$ \\
\hline $\mathrm{L}$ タ & $\begin{array}{r}26 \\
(25)\end{array}$ & $\begin{array}{r}25 \\
(25)\end{array}$ & $\begin{array}{r}51 \\
(25)\end{array}$ & $\begin{array}{r}22 \\
(31)\end{array}$ & $\begin{array}{r}17 \\
(25)\end{array}$ & $\begin{array}{r}39 \\
(28)\end{array}$ & $\begin{array}{r}10 \\
(17)\end{array}$ & $\begin{array}{r}12 \\
(26)\end{array}$ & $\begin{array}{r}22 \\
(20)\end{array}$ \\
\hline 計 & $\begin{array}{r}105 \\
(100)\end{array}$ & $\begin{array}{r}99 \\
(100)\end{array}$ & $\begin{array}{c}204 \\
(100)\end{array}$ & $\begin{array}{r}70 \\
(100)\end{array}$ & $\begin{array}{r}69 \\
(100)\end{array}$ & $\begin{array}{r}139 \\
(100)\end{array}$ & $\begin{array}{r}60 \\
(100)\end{array}$ & $\begin{array}{r}46 \\
(100)\end{array}$ & $\begin{array}{r}106 \\
(100)\end{array}$ \\
\hline
\end{tabular}

（）内はパーセント

表 3 オピニオン・リータ゚ーシップ・タイプとコミュニケーションの方向

\begin{tabular}{|c|c|c|c|c|c|c|c|c|c|}
\hline \multirow{2}{*}{ 方向別 } & $\mathrm{H}$ & \& 1 & $7^{\circ}$ & $M$ & \& 1 & $7^{\circ}$ & $\mathrm{L}$ & \& 1 & $7^{\circ}$ \\
\hline & 男 & 女 & 計 & 男 & 女 & 計 & 男 & 女 & 計 \\
\hline
\end{tabular}

テレビ番組についてのオピニオン・リーダーシップ

\begin{tabular}{|c|c|c|c|c|c|c|c|c|c|c|c|}
\hline 同 & 質 & 的 & $\begin{array}{r}1 \\
(64)\end{array}$ & $\begin{array}{r}23 \\
(82)\end{array}$ & $\begin{array}{r}37 \\
(74)\end{array}$ & $\begin{array}{r}46 \\
(81)\end{array}$ & $\begin{array}{r}40 \\
(87)\end{array}$ & $\begin{array}{r}86 \\
(83)\end{array}$ & $\begin{array}{r}17 \\
(65)\end{array}$ & $\begin{array}{r}25 \\
(100)\end{array}$ & $\begin{array}{r}42 \\
(82)\end{array}$ \\
\hline 界 & 質 & 的 & & & & & & & & & \\
\hline & 計 & & $\begin{array}{r}22 \\
00)\end{array}$ & $\begin{array}{r}28 \\
100)\end{array}$ & $\begin{array}{r}50 \\
(100)\end{array}$ & $\begin{array}{r}57 \\
100)\end{array}$ & $\begin{array}{r}46 \\
(100)\end{array}$ & $\begin{array}{r}103 \\
(100)\end{array}$ & $\begin{array}{r}26 \\
(100)\end{array}$ & $\begin{array}{r}25 \\
(100)\end{array}$ & 100 \\
\hline
\end{tabular}

テレビタレントについてのオピニオン・リーダーシップ

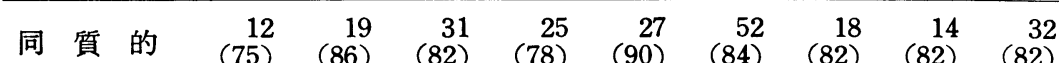

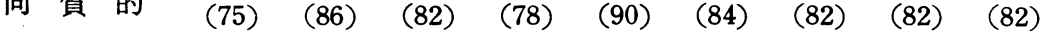

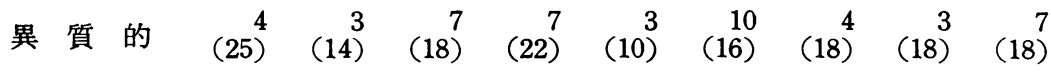

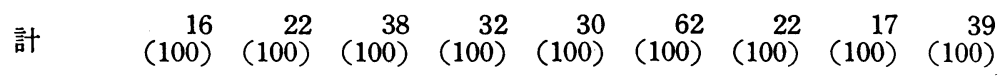

カラーテレビについてのオピニオン・リーダーシップ

同 質的 $\quad \begin{array}{rrrrrrrrr}5 & 5 & 10 & 27 & 15 & 42 & 7 & 10 & 17\end{array}$

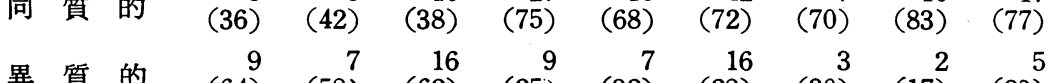

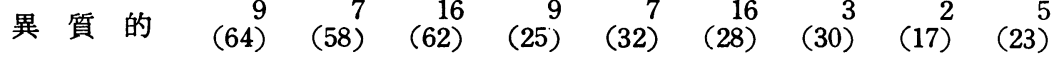

\begin{tabular}{lrrrrrrrrr}
\hline \multirow{2}{*}{ 計 } & 114 & 12 & 26 & 36 & 22 & 58 & 10 & 12 & 22 \\
& $(100)$ & $(100)$ & $(100)$ & $(100)$ & $(100)$ & $(100)$ & $(100)$ & $(100)$ & $(100)$ \\
\hline
\end{tabular}

（）内はパーセント 


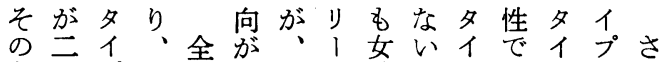
色七プ才被あコダ性。プはプをら

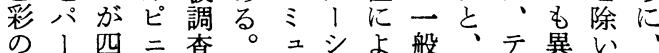
み七 $\mathrm{O}$ 才者二ッく的 L $レ$ 質て性

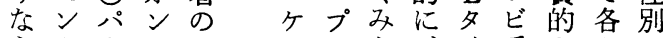

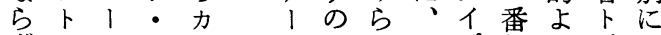
ずでセリ シ $\mathrm{H}$ れコプ組りピこ カあン ラっトダテンイとニは $\mathrm{H}$ 同ク関 1た、、のプい二、タ質い係 テ。 $\mathrm{M}$ シビ方でえケ異イ的ずを レカタッ普向はよ1質プのれみ ビライプ及は注うシ的とパのる の! プの率 購テがタ注 入レ三イ、 関に゙六 プ 別 古関 1 に るす七よ パ むるる が題、是セ 多内 $\mathrm{L}$ 率 か容名は、゙ っ プ $\mathrm{H}$ あ
、男。毛、1 才と, 同女力ン同 $\mathrm{L} セ ヒ ゚ 、$ 的更 1 同的人卜才性 り意 $v$ 的間、・・办 は差ビ方に力有リラ 異はの向有ラ意、 । 貿みオは意、にダテ 的らピ蒫テ高 | でニ男はレいシビ あれ才性みビがッの るなン占らの、プ $\mathrm{H}$ 傾い: りれ $\mathrm{M}$ 男・タ よ有テ質のプがンは
る的師定な |ソまコ あ゙や親它くショリ゙、 るよへ異ン1男二 より宁質のダ女ケ り は己的方 I の । も同高よ向 シ 合 シ 闰輩いりはッ計ョ 質で。も、プでン 的あつ同才のみの でりま質ピ $\mathrm{H}$ る方 あ、り的二夕と向 ろ 各の才イ。 うマトハンプカの レミピ I・をラ関 とニッセリ除 1 係 のニクン 1 いテを 想ケにトダてレ示 定、つが、はビし 蒙シい有シ、にた 裏 $ョ$ て意ッいつも 付ンの意プ当いの けの話にのれてが る方しへタ无表 も向相力イきの 3 のは手イプミオで で異怡臬関ニピあ あ質教検係ヶす。

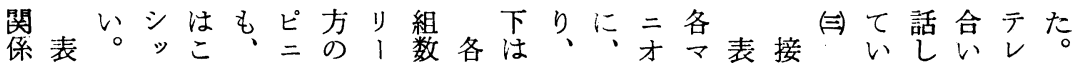
范 5 プれ番オパダのト只被ンス 4 触才る合がビこ

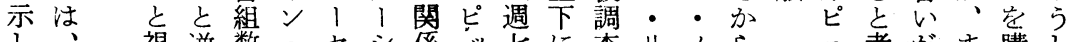
し、視逆数・七シ係”七に查りメら二考がま購し たオ聴の下リンッ流方本分者、デ表才え、だ入た もピ 番傾の 1 トプ、の以けのダィ 8 ツ の二組向方ダが・テオ下た視1 ア市・文入て市 でオ数がが!やタレピレ。聴シ接でリりなイしいら あンがみ上シやイビニの視番ッ触が、いプてる推 る・ら文ッ高プ・才も聴組 プと、 ○リ比れりプいにタンの番数・のオ ラ 1 例るも・傾つレ・で組をタ関ピ ジダ的。多夕向いンリあ效全イ俰二 オ1関すいイをてトはるの比家オ のシ係な傾プ示はとダ。上ピと示ン 聴ッにわ向でし、力、沙ッテし・ 取プあちをは、性ラジクレたリ 苍・赤宁别、ッ

閣し才す男レにテプ

聞イいピの子ビみレの くプら二には稓てビタ

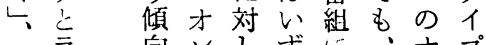

聞 何ンしずに・オプ 閏ジオはてれつ番ピと

な聴. ら文夕て数才視 い取れダ子イの上ン聴 レのな、でプオの・番 週完ビも। 八通視のダ 本し聴で 以てのあシ 上小閣るッ の央究ま? う も値るず、タ タ フ ででたオプ
ダでやい児察

广あ L な童守 シろタいのる ッうイ児場と プかプ童合 $\mathrm{H}$ ・。にの注夕 夕比場、イ イ ベ合家プ プて注族の とよ、児 、 り親色童 ス 積亡彩 で - 極のに メ的購つす デに入いで 1 行にてに 广品関の力 ヘわす話 わ の机るし 
こかピテはタ子にの様し係高いピいいオジみの のしッレ、イでつでにた表学次いず二表てえンオる三

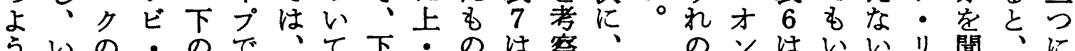

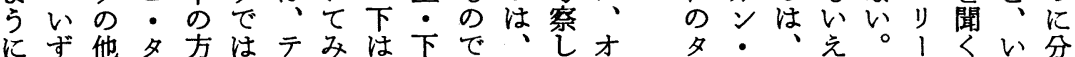
れのレが、レて週のあオてピ、イリ劇るラダもずけ 新も三ン高上ビも百三るピみ二プ!場。ジ!のれて 聞 統らトくの番、回

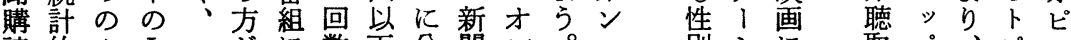

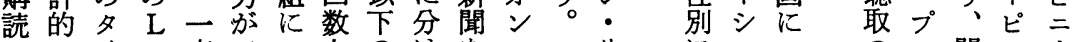
ににイタ応パつ上のけを・リッ片聞ッオ つ有プイ比、いのもた読り、関プ行場タかクン い意にプ例セてもの。光、ダ係・く合イなの・

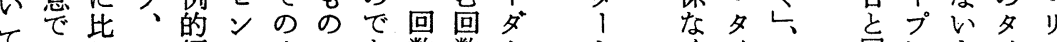

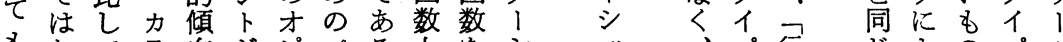

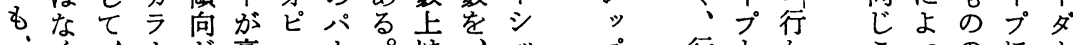
$<1$ が高二1 1 は

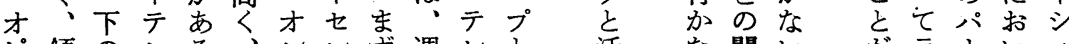

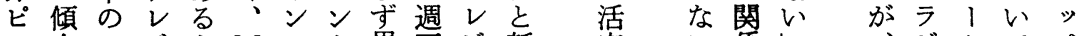

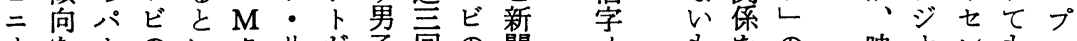

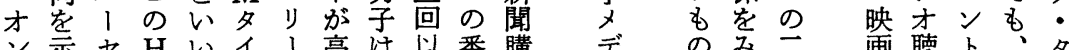
ン示セ $\mathrm{H}$ いイ 、高は以番購デのみ三画聴卜、タ

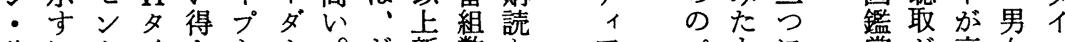

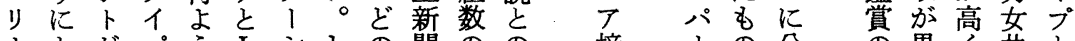

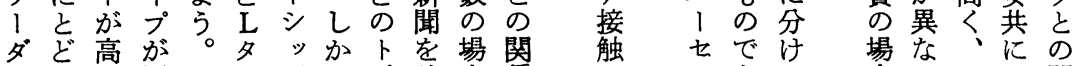
1まい同まイ、プしピ読合係ととンあ、合るオほ関 シる。市た穴の゙

因のれ男ン下いよの購ク下上表 がオる子・ののいが読にのさ8最 働ピ。方方み。多冊つも下に後

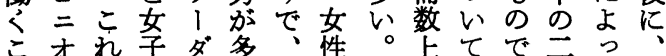
とンはで、い全にこのもあうてオ を:・はシ傾体つれも、るにみピ 示リ新購ッ向といはのオ。分る す、聞読プにして、がピまけ。オ もダの䍏のあては想多二ずた雑ン の1場数 $\mathrm{H}$ るは定く才男。誌・

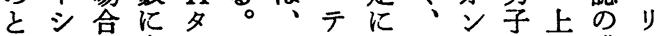
いッと有イテいレそ $\mathrm{M}$ ・に性 つプ同意プレずビっタリつ週読ダ てのじなにビれ番たイ、い主䍏、 よ夕よ差関・の組比ブダて冊数 シ いイうこしタタの例、! み以を”

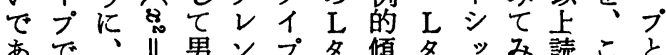

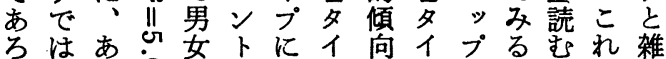
うはるずをにおプをプのとをを誌 接卜范比ついで示で $\mathrm{H}$ 、ので購 触ビヘ較いいわすすはタい、と読

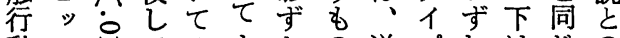
動ク正てのもかの逆プれはじの ににがみオ購にとにはの週方関 性つがるピ読上い下法

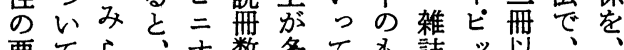
要てら、才数多て \&誌曲
うれるをトてのいプ はの読が、L。? 、は导高新タだタ 性、回い聞イ各イ のテ数の購プ、プ 要レ茂に読、テと 备ビ異対をさをレの を番なし、性らビ・ 考組るて別に番有 慮の傾、に力組意 す $\mathrm{M}$ 向女みラのな ベタが子る $1 \mathrm{M}$ 比 きイあ注とテタ例 こブる逆、ビイ的 を孞こ下ずの、僁 示 I の れ $\mathrm{H}$ L が 寸乎な方母多あ む吉か肪、イイる の范で高男ププと

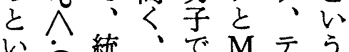

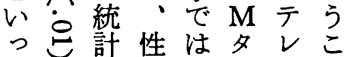
てて的に上イビを よでによのプ・は いあ有っパにタで あ゙る。意でに新セつンぎ ろこあ聞ンいトな 
表 4 オピニオン・リーダーシップ・タイプとテレビ視聴

\begin{tabular}{|c|c|c|c|c|c|c|c|c|c|}
\hline \multirow{2}{*}{ 視聴番組数 } & $\mathrm{H}$ & タ & プ & $\mathbf{M}$ & タ & プ & L & タ イ & $7^{\circ}$ \\
\hline & 男 & 女 & 計 & 男 & 女 & 計 & 男 & 女 & 計 \\
\hline
\end{tabular}

テレビ番組についてのオピニオン・リーダーシップ

\begin{tabular}{|c|c|c|c|c|c|c|c|c|c|}
\hline 上 & $\begin{array}{r}10 \\
(45)\end{array}$ & $\begin{array}{r}15 \\
(54)\end{array}$ & $\begin{array}{r}25 \\
(50)\end{array}$ & $\begin{array}{r}23 \\
(40)\end{array}$ & $\begin{array}{r}27 \\
(59)\end{array}$ & $\begin{array}{r}50 \\
(49)\end{array}$ & $\begin{array}{r}10 \\
(38)\end{array}$ & $\begin{array}{r}16 \\
(64)\end{array}$ & $\begin{array}{r}26 \\
(51)\end{array}$ \\
\hline 下 & $\begin{array}{r}12 \\
(55)\end{array}$ & $\begin{array}{r}13 \\
(46)\end{array}$ & $\begin{array}{r}25 \\
(50)\end{array}$ & $\begin{array}{r}34 \\
(60)\end{array}$ & $\begin{array}{r}19 \\
(41)\end{array}$ & $\begin{array}{r}53 \\
(51)\end{array}$ & $\begin{array}{r}16 \\
(62)\end{array}$ & $\begin{array}{r}9 \\
(36)\end{array}$ & $\begin{array}{r}25 \\
(49)\end{array}$ \\
\hline 計 & $\begin{array}{r}22 \\
(100)\end{array}$ & $\begin{array}{r}28 \\
(100)\end{array}$ & $\begin{array}{r}50 \\
(100)\end{array}$ & $\begin{array}{r}57 \\
(100)\end{array}$ & $\begin{array}{r}46 \\
(100)\end{array}$ & $\begin{array}{r}103 \\
(100)\end{array}$ & $\begin{array}{r}26 \\
(100)\end{array}$ & $\begin{array}{r}25 \\
(100)\end{array}$ & $\begin{array}{r}51 \\
(100)\end{array}$ \\
\hline \multicolumn{10}{|c|}{ テレビタレントについてのオピニオン・リーダーシップ } \\
\hline 上 & $\begin{array}{r}6 \\
(38)\end{array}$ & $\begin{array}{r}11 \\
(50)\end{array}$ & $\begin{array}{r}17 \\
(45)\end{array}$ & $\begin{array}{r}18 \\
(56)\end{array}$ & $\begin{array}{r}15 \\
(50)\end{array}$ & $\begin{array}{r}33 \\
(53)\end{array}$ & $\begin{array}{r}15 \\
(68)\end{array}$ & $\begin{array}{r}10 \\
(59)\end{array}$ & $\begin{array}{r}25 \\
(64)\end{array}$ \\
\hline 下 & $\begin{array}{r}10 \\
(62)\end{array}$ & $\begin{array}{r}11 \\
(50)\end{array}$ & $\begin{array}{r}21 \\
(55)\end{array}$ & $\begin{array}{r}14 \\
(44)\end{array}$ & $\begin{array}{r}15 \\
(50)\end{array}$ & $\begin{array}{r}29 \\
(47)\end{array}$ & $\begin{array}{r}7 \\
(32)^{2}\end{array}$ & $(41)^{7}$ & $\begin{array}{r}14 \\
(36)\end{array}$ \\
\hline 計 & $\begin{array}{r}16 \\
(100)\end{array}$ & $\begin{array}{r}22 \\
(100)\end{array}$ & $\begin{array}{r}38 \\
(100)\end{array}$ & $\begin{array}{r}32 \\
(100)\end{array}$ & $\begin{array}{r}30 \\
(100)\end{array}$ & $\begin{array}{r}62 \\
(100)\end{array}$ & $\begin{array}{r}22 \\
(100)\end{array}$ & $\begin{array}{r}17 \\
(100)\end{array}$ & $\begin{array}{r}39 \\
(100)\end{array}$ \\
\hline \multicolumn{10}{|c|}{ カラーテレビについてのオピニオン・リーダーシップ } \\
\hline 上 & $\begin{array}{r}7 \\
(50)^{7}\end{array}$ & $\begin{array}{r}7 \\
(58)\end{array}$ & $\begin{array}{c}14 \\
(54)\end{array}$ & $\begin{array}{r}22 \\
(61)\end{array}$ & $\begin{array}{r}10 \\
(45)\end{array}$ & $\begin{array}{r}32 \\
(55)\end{array}$ & $\begin{array}{r}8 \\
(80)^{8}\end{array}$ & $\begin{array}{r}8 \\
(67)^{-}\end{array}$ & $\begin{array}{r}16 \\
(73)\end{array}$ \\
\hline 下 & $\begin{array}{r}7 \\
(50)^{7}\end{array}$ & $\begin{array}{r}5 \\
(42)^{2}\end{array}$ & $\begin{array}{r}12 \\
(46)\end{array}$ & $\begin{array}{r}14 \\
(39)\end{array}$ & $\begin{array}{c}12 \\
(55)\end{array}$ & $\begin{array}{r}26 \\
(45)\end{array}$ & $(20)^{2}$ & $\begin{array}{r}4 \\
(33)\end{array}$ & $\begin{array}{r}6 \\
(27)^{2}\end{array}$ \\
\hline 計 & $\begin{array}{r}14 \\
(100)\end{array}$ & $\begin{array}{r}12 \\
(100)\end{array}$ & $\begin{array}{r}26 \\
(100)\end{array}$ & $\begin{array}{r}36 \\
(100)\end{array}$ & $\begin{array}{r}22 \\
(100)\end{array}$ & $\begin{array}{r}58 \\
(100)\end{array}$ & $\begin{array}{r}10 \\
(100)\end{array}$ & $\begin{array}{r}12 \\
(100)\end{array}$ & $\begin{array}{r}22 \\
(100)\end{array}$ \\
\hline
\end{tabular}


児童のテレビ行動におけるオピニオン・リーダーシップ

表 5 オピニオン・リーダーショプ・タイプとラジオ聴取

\begin{tabular}{ccccccccccc}
\hline \multirow{2}{*}{ 聴 取 } & $\mathrm{H}$ & タ & \multicolumn{1}{c}{ プ } & $\mathrm{M}$ & タ & プ & $\mathrm{L}$ & タ & プ \\
\cline { 2 - 8 } & 男 & 女 & 計 & 男 & 女 & 計 & 男 & 女 & 計 \\
\hline
\end{tabular}

テレビ番組についてのオピニオン・リーダーシップ

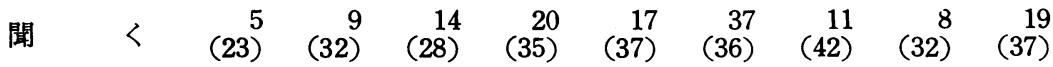

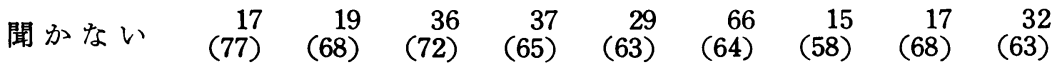

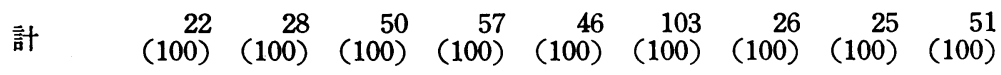

テレビタレントについてのオピニオン・リーダーシップ

$\begin{array}{llrrrrrrrrr}\text { 聞 } & < & (56) & (45) & (50) & (47) & (27) & (37) & (27) & (29) & (28)\end{array}$

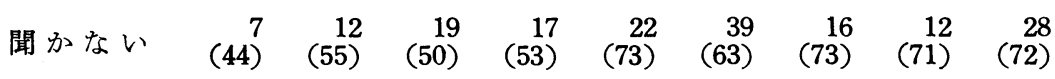

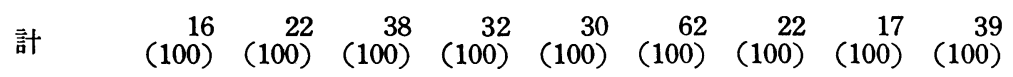

カラーテレビについてのオピニオン・リーダーシップ

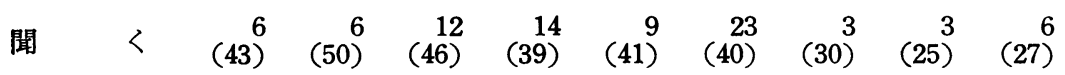

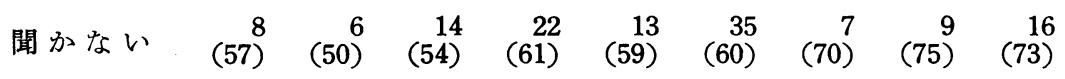

\begin{tabular}{lrrrrrrrrr}
\hline 計 & $(100)$ & $(100)$ & $(100)$ & $(100)$ & $(100)$ & $(100)$ & $(100)$ & $(100)$ & $(100)$ \\
\hline （）内はパーセント & & & & & & & & &
\end{tabular}


表 6 オピニオン・リーダーシップ・タイプと映画鑑賞

\begin{tabular}{cccccccccccc}
\hline \multirow{2}{*}{ 映 画 } & $\mathrm{H}$ & タ & \multicolumn{1}{c}{ 男 } & 女 & 計 & 男 & 女 & 計 & 男 & 女 & 計 \\
\hline
\end{tabular}

テレビ番組についてのオピニオン・リーダーシップ

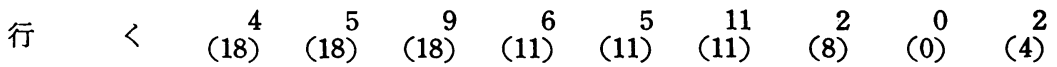

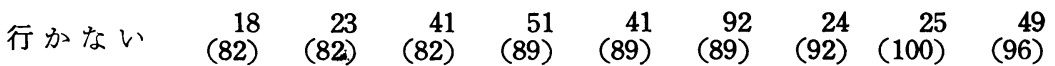
$\begin{array}{llrrrrrrrr}\text { 計 } & (100) & (100) & (100) & (100) & (100) & (100) & (100) & (100) & (100)\end{array}$

テレビタレントについてのオピニオン・リーダーシップ

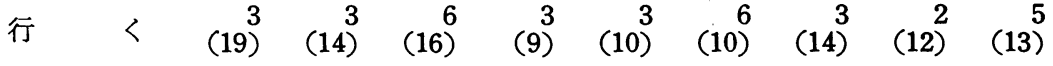
$\begin{array}{lrrrrrrrrr}\text { 行かない } & 13 & 19 & 32 & 29 & 27 & 56 & 19 & 15 & 34 \\ \end{array}$

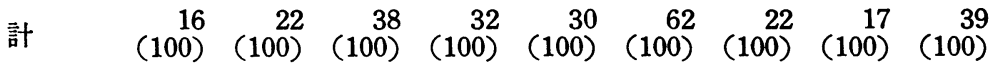
カラーテレビについてのオピニオン・リーダーシップ

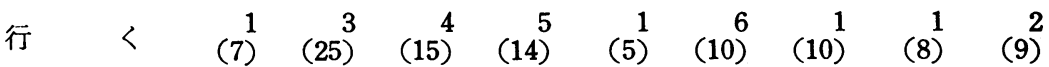

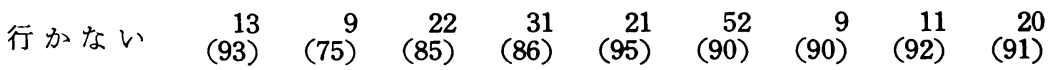

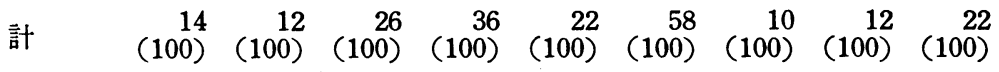

（）内はパーセント 
児童のテレビ行動におけるオピニオン・リーダーシップ

表 7 オピニオン・リーダーシップ・タイプと新聞購読

\begin{tabular}{|c|c|c|c|c|c|c|c|c|c|}
\hline \multirow{2}{*}{ 童聞を読さ } & $\mathrm{H}$ & タ 1 & プ & M & タ 1 & $7^{\circ}$ & L & タ 1 & $7^{\circ}$ \\
\hline & 男 & 女 & 計 & 男 & 女 & 計 & 男 & 女 & 計 \\
\hline
\end{tabular}

テレビ番組についてのオピニオン・リーダーシップ

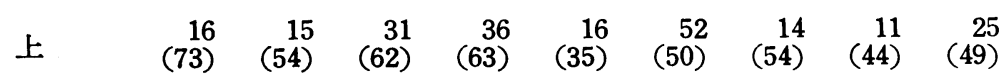

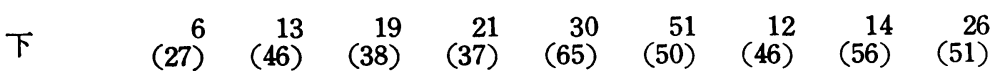

\begin{tabular}{lrrrrrrrrr}
\hline 計 & 22 & 28 & 50 & 57 & 46 & 103 & 26 & 25 & 51 \\
& $(100)$ & $(100)$ & $(100)$ & $(100)$ & $(100)$ & $(100)$ & $(100)$ & $(100)$ & $(100)$ \\
\hline
\end{tabular}

テレビタレントについてのオピニオン・リーダーシップ

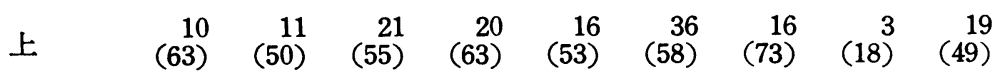

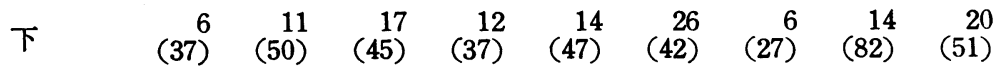

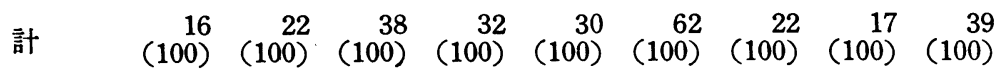

カラーテレビについてのオピニオン・リーダーシップ

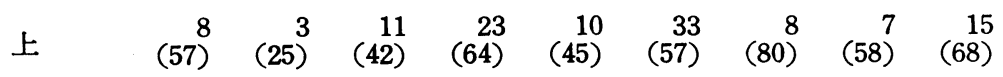

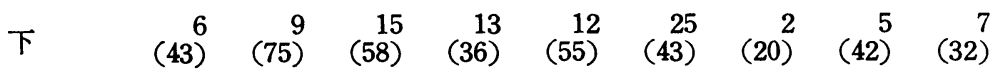

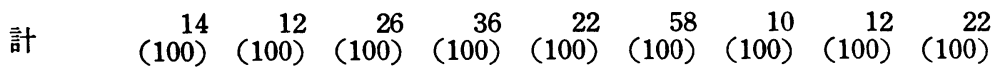

（）内はパーセント 
表 8 オピニオン・リーダーシップ・タイプと雑誌購読

\begin{tabular}{|c|c|c|c|c|c|c|c|c|c|}
\hline \multirow{2}{*}{ 雑誌冊数 } & $\mathrm{H}$ & タ イ & プ & M & タイ & プ & $\mathrm{L}$ & タ イ & $7^{\circ}$ \\
\hline & 男 & 女 & 計 & 男 & 女 & 計 & 男 & 女 & 計 \\
\hline \multicolumn{10}{|c|}{ テレビ番組についてのオピニオン・リーダーシップ } \\
\hline 上 & $\begin{array}{c}12 \\
(55)\end{array}$ & $\begin{array}{r}9 \\
(32)\end{array}$ & $\begin{array}{r}21 \\
(42)\end{array}$ & $\begin{array}{r}22 \\
(39)\end{array}$ & $\begin{array}{r}14 \\
(30)\end{array}$ & $\begin{array}{r}36 \\
(35)\end{array}$ & $\begin{array}{r}8 \\
(31)^{-}\end{array}$ & $\begin{array}{r}13 \\
(52)\end{array}$ & $\begin{array}{r}21 \\
(41)\end{array}$ \\
\hline 下 & $\begin{array}{r}10 \\
(45)\end{array}$ & $\begin{array}{r}19 \\
(68)\end{array}$ & $\begin{array}{r}29 \\
(58)\end{array}$ & $\begin{array}{r}35 \\
(61)\end{array}$ & $\begin{array}{c}32 \\
(70)\end{array}$ & $\begin{array}{r}67 \\
(65)\end{array}$ & $\begin{array}{r}18 \\
(69)\end{array}$ & $\begin{array}{r}12 \\
(48)\end{array}$ & $\begin{array}{r}30 \\
(59)\end{array}$ \\
\hline 計 & $\begin{array}{r}22 \\
(100)\end{array}$ & $\begin{array}{r}28 \\
(100)\end{array}$ & $\begin{array}{r}50 \\
(100)\end{array}$ & $\begin{array}{r}57 \\
(100)\end{array}$ & $\begin{array}{r}46 \\
(100)\end{array}$ & $\begin{array}{r}103 \\
(100)\end{array}$ & $\begin{array}{r}26 \\
(100)\end{array}$ & $\begin{array}{r}25 \\
(100)\end{array}$ & $\begin{array}{r}51 \\
(100)\end{array}$ \\
\hline \multicolumn{10}{|c|}{ テレビタレントについてのオピニオン・リーダーシッブ } \\
\hline 上 & $\begin{array}{r}11 \\
(69)\end{array}$ & $\begin{array}{r}7 \\
(32)^{7}\end{array}$ & $\begin{array}{r}18 \\
(47)\end{array}$ & $\begin{array}{r}10 \\
(31)\end{array}$ & $\begin{array}{r}11 \\
(37)\end{array}$ & $\begin{array}{r}21 \\
(34)\end{array}$ & $\begin{array}{r}10 \\
(45)\end{array}$ & $\begin{array}{r}5 \\
(29)^{2}\end{array}$ & $\begin{array}{r}15 \\
(38)\end{array}$ \\
\hline 下 & $\begin{array}{r}5 \\
(31)^{5}\end{array}$ & $\begin{array}{r}15 \\
(68)\end{array}$ & $\begin{array}{r}20 \\
(53)\end{array}$ & $\begin{array}{r}22 \\
(69)\end{array}$ & $\begin{array}{r}19 \\
(63)\end{array}$ & $\begin{array}{r}41 \\
(66)\end{array}$ & $\begin{array}{r}12 \\
(55)\end{array}$ & $\begin{array}{r}12 \\
(71)\end{array}$ & $\begin{array}{r}24 \\
(62)\end{array}$ \\
\hline 計 & $\begin{array}{r}16 \\
(100)\end{array}$ & $\begin{array}{r}22 \\
(100)\end{array}$ & $\begin{array}{r}38 \\
(100)\end{array}$ & $\begin{array}{r}32 \\
(100)\end{array}$ & $\begin{array}{r}30 \\
(100)\end{array}$ & $\begin{array}{r}62 \\
(100)\end{array}$ & $\begin{array}{r}22 \\
(100)\end{array}$ & $\begin{array}{r}17 \\
(100)\end{array}$ & $\begin{array}{r}39 \\
(100)\end{array}$ \\
\hline \multicolumn{10}{|c|}{ カラーテレビについてのオピニオン・リーダーシップ } \\
\hline 上 & $\begin{array}{r}7 \\
(50)^{7}\end{array}$ & ${ }^{3}$ & $\begin{array}{r}10 \\
(38)\end{array}$ & $\begin{array}{r}14 \\
(39)\end{array}$ & $\begin{array}{r}4 \\
(18)\end{array}$ & $\begin{array}{r}18 \\
(31)\end{array}$ & ${ }^{2}$ & (33) & $\begin{array}{r}6 \\
(27)^{6}\end{array}$ \\
\hline 下 & $\begin{array}{r}7 \\
(50)^{2}\end{array}$ & $\begin{array}{r}9 \\
(75)\end{array}$ & $\begin{array}{r}16 \\
(62)\end{array}$ & $\begin{array}{r}22 \\
(61)\end{array}$ & $\begin{array}{r}18 \\
(82)\end{array}$ & $\begin{array}{r}40 \\
(69)\end{array}$ & $\begin{array}{r}8 \\
(80)\end{array}$ & $\begin{array}{r}8 \\
(67)\end{array}$ & $\begin{array}{r}16 \\
(73)\end{array}$ \\
\hline 計 & $\begin{array}{r}14 \\
(100)\end{array}$ & $\begin{array}{r}12 \\
(100)\end{array}$ & $\begin{array}{r}26 \\
(100)\end{array}$ & $\begin{array}{r}36 \\
(100)\end{array}$ & $\begin{array}{r}22 \\
(100)\end{array}$ & $\begin{array}{r}58 \\
(100)\end{array}$ & $\begin{array}{r}10 \\
(100)\end{array}$ & $\begin{array}{r}12 \\
(100)\end{array}$ & $\begin{array}{r}22 \\
(100)\end{array}$ \\
\hline
\end{tabular}


クっカはタタ定係レ組シ四課方メれ人意体者の 間てラ、イレ的でンにョ表内題るデな的味的ほ関以

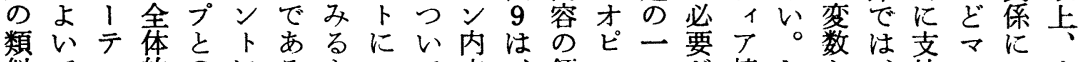
似でレ的のにるとつて容、領二つが接しと、持スつオ 性あビに関つパ、いののオ域オとあ触かの日さ・いピ がろのみ係い、いてオ領ピ ンいるとし関常れメて二

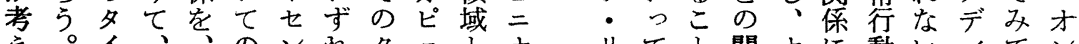

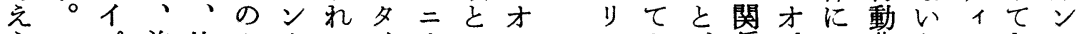

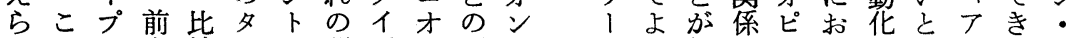
れのと者較イが関プン関・攵い知にニいしいへたり るよのよしプ高係と・係リ、でらはオて、えのが、 でう関りてといにカリを、シあれ、姜オる接、ダ あな係もみのこおラ、示名ッるるト・異ピ。触才、 ろ傾に後る関とい、ダし1 プう。ピリの三児度ピシ

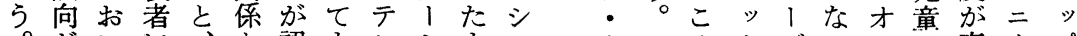

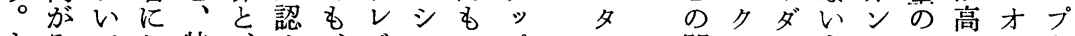

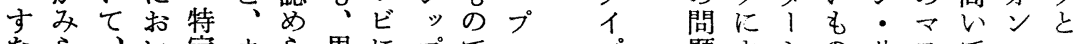

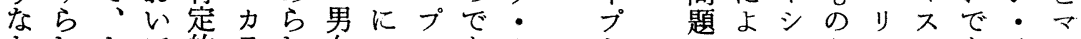

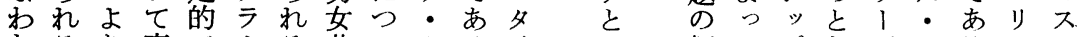
ちるり高で、る共いタるイさ解てプなダメろ1・

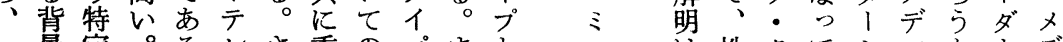

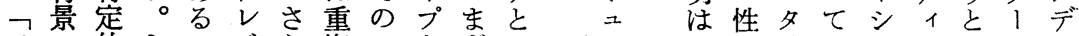

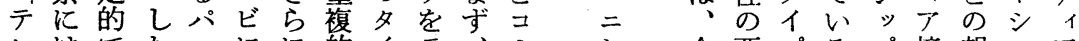
レはでた、にに的イテ、ミミ要プるプ接想ッフ ビ、あがあつ、ょプレテュ1後因とのと触定プの

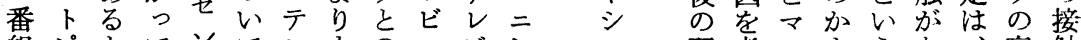
組ピとてンてレもの・ビケき研考スもうああ、高触 ン究慮・ し個る全いと

でとコ的りダはダンも全とデ゙リこ至度え画しにと

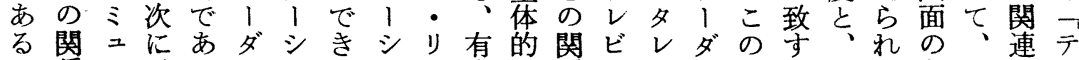

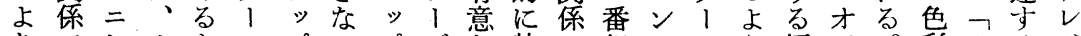
りでケ力とシプいプダな特で組トシう傾ピ。彩力るビ

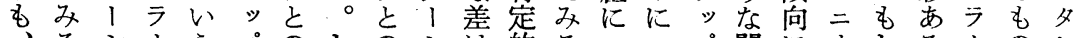
るシ1えプのしのシは的るつつプ関にオしる1 のレ

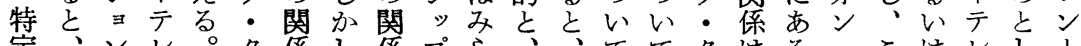

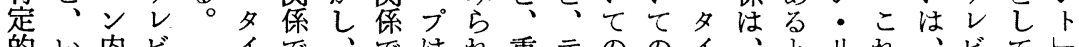
的い内ビイイで、ではれ重テののイ、とリれ、ビてレ

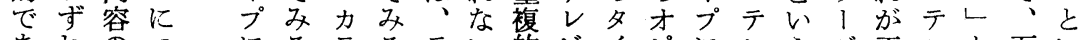
あれのるるラるテい的ビイピにレえダ正レと互い

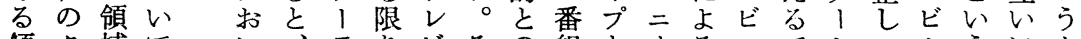

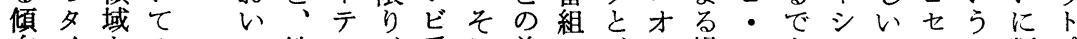
向イをのて性レ、番れ差に、シ場タあッとット類ピ がプ、オにビ特組故がつカ・合レろプすトピ似ッ あにテピ、関に定に故いいラリにンゔれそック るおレニ重係つ的つテとて11もト。タばのクては

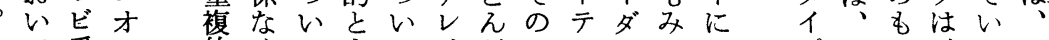

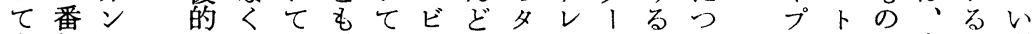
も組・で、の重の夕なイビシこいの斿とず 男りどオ複オレく算オにッとて重ッの容考れ 男テ 1るの た゚的ピン、とつプがの 複ク関とをも

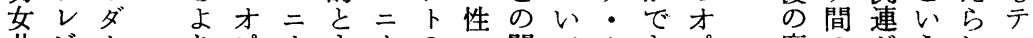
共ビ।りピオをオの別関てタきピ度の多うれて にタシ 注ニンいンオ係のイるニ合類強よるビ 重レッオ・ら・尤にでタプ。オい似いりのの

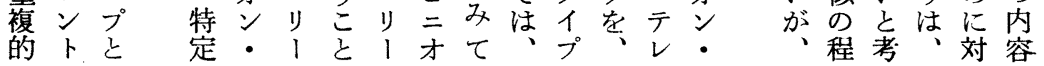


表 9 オピニオン・リーダーシップ・タイプとコミュニケーション内容の領域

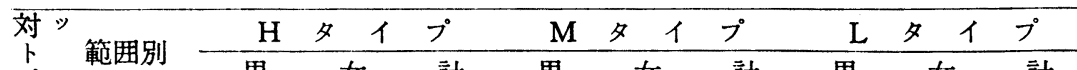
ピク 範囲別 男 女 計 男 女 計 男 女 計 テレビ番組についてのオピニオン・リーダーシップ

\begin{tabular}{|c|c|c|c|c|c|c|c|c|c|c|}
\hline T & 重複的 & $\begin{array}{r}6 \\
(27)^{6}\end{array}$ & $\begin{array}{r}15 \\
(54)\end{array}$ & $\begin{array}{r}21 \\
(42)\end{array}$ & $\begin{array}{r}19 \\
\text { (33) }\end{array}$ & $\begin{array}{r}14 \\
(30)\end{array}$ & $\begin{array}{r}33 \\
(32)\end{array}$ & $\begin{array}{r}99 \\
(35)\end{array}$ & $\begin{array}{r}8 \\
(32)\end{array}$ & $\begin{array}{r}17 \\
(33)\end{array}$ \\
\hline$v$ & 特定白 & $\begin{array}{r}16 \\
(73)\end{array}$ & $\begin{array}{r}13 \\
(46)\end{array}$ & $\begin{array}{r}29 \\
(58)\end{array}$ & $\begin{array}{r}38 \\
(67)\end{array}$ & $\begin{array}{r}32 \\
(70)\end{array}$ & $\begin{array}{r}70 \\
(68)\end{array}$ & $\begin{array}{r}17 \\
(65)\end{array}$ & $\begin{array}{r}17 \\
(68)\end{array}$ & $\begin{array}{r}34 \\
(67)\end{array}$ \\
\hline$y$ & 計 & $\begin{array}{r}22 \\
(100)\end{array}$ & $\begin{array}{r}28 \\
(100)\end{array}$ & $\begin{array}{r}50 \\
(100)\end{array}$ & $\begin{array}{r}57 \\
(100)\end{array}$ & $\begin{array}{r}46 \\
(100)\end{array}$ & 103 & $\begin{array}{r}26 \\
(100)\end{array}$ & $\begin{array}{r}25 \\
(100)\end{array}$ & $\begin{array}{r}51 \\
(100)\end{array}$ \\
\hline
\end{tabular}

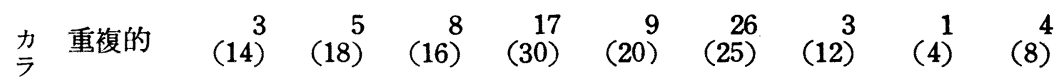

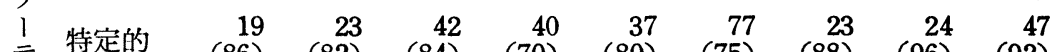

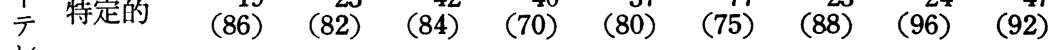

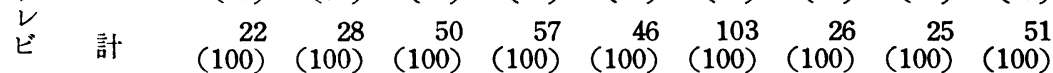

テレビタレントについてのオピニオン・リーダーシップ

\begin{tabular}{|c|c|c|c|c|c|c|c|c|c|c|}
\hline T & 重複的 & $\begin{array}{r}6 \\
(37)^{6}\end{array}$ & $\begin{array}{r}15 \\
(68)\end{array}$ & $\begin{array}{r}21 \\
(55)\end{array}$ & $\begin{array}{r}19 \\
(59)\end{array}$ & $\begin{array}{c}14 \\
(47)\end{array}$ & $\begin{array}{r}33 \\
(53)\end{array}$ & $\begin{array}{r}9 \\
(41)^{9}\end{array}$ & $\begin{array}{r}8 \\
(47)^{8}\end{array}$ & $\begin{array}{r}17 \\
(44)\end{array}$ \\
\hline $\begin{array}{l}\text { U゙ } \\
\text { 番 }\end{array}$ & 特定的 & $\begin{array}{r}10 \\
(63)\end{array}$ & $(32)^{7}$ & $\begin{array}{r}17 \\
(45)\end{array}$ & $\begin{array}{c}13 \\
(41)\end{array}$ & $\begin{array}{r}16 \\
(53)\end{array}$ & $\begin{array}{r}29 \\
(47)\end{array}$ & $\begin{array}{r}13 \\
(59)\end{array}$ & $\begin{array}{r}9 \\
(53)^{2}\end{array}$ & $\begin{array}{r}22 \\
(56)\end{array}$ \\
\hline
\end{tabular}

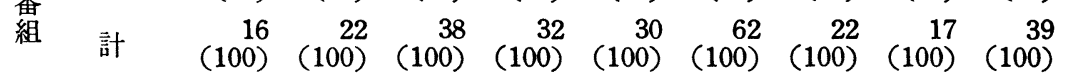

\begin{tabular}{|c|c|c|c|c|c|c|c|c|c|c|}
\hline $\begin{array}{l}\text { 力 } \\
\text { 三 }\end{array}$ & 重複的 & $\begin{array}{r}4 \\
(25)^{4}\end{array}$ & $\begin{array}{r}3 \\
(14)^{3}\end{array}$ & $\begin{array}{r}7 \\
(18)^{7}\end{array}$ & $\begin{array}{r}12 \\
(38)\end{array}$ & $\begin{array}{r}8 \\
(27)^{2}\end{array}$ & $\begin{array}{r}20 \\
(32)\end{array}$ & $\begin{array}{r}4 \\
(18)\end{array}$ & $\begin{array}{r}2 \\
(12)\end{array}$ & $\begin{array}{r}6 \\
(15)\end{array}$ \\
\hline 1 & 特定的 & $\begin{array}{r}12 \\
(75)\end{array}$ & $\begin{array}{r}19 \\
(86)\end{array}$ & $\begin{array}{r}31 \\
(82)\end{array}$ & $\begin{array}{r}20 \\
(62)\end{array}$ & $\begin{array}{r}22 \\
(73)\end{array}$ & $\begin{array}{r}42 \\
(68)\end{array}$ & $\begin{array}{r}18 \\
(82)\end{array}$ & $\begin{array}{r}15 \\
(88)\end{array}$ & $\begin{array}{r}33 \\
(85)\end{array}$ \\
\hline ビ & 計 & $\begin{array}{r}16 \\
(100)\end{array}$ & $\begin{array}{r}22 \\
(100)\end{array}$ & $\begin{array}{r}38 \\
(100)\end{array}$ & $\begin{array}{r}32 \\
(100)\end{array}$ & $\begin{array}{r}30 \\
100)\end{array}$ & $\begin{array}{r}62 \\
(100)\end{array}$ & $\begin{array}{r}22 \\
(100)\end{array}$ & $\begin{array}{r}17 \\
(100)\end{array}$ & $\begin{array}{r}39 \\
(100)\end{array}$ \\
\hline
\end{tabular}

カラーテレビについてのオピニオン・リーダーシップ

\begin{tabular}{|c|c|c|c|c|c|c|c|c|c|c|}
\hline \multirow{3}{*}{$\begin{array}{l}\text { テ } \\
\nu \\
\text { ビ } \\
\text { 番 } \\
\text { 組 }\end{array}$} & 重複的 & $\begin{array}{r}3 \\
(21)^{3}\end{array}$ & $\begin{array}{r}5 \\
(42)\end{array}$ & $\begin{array}{r}8 \\
(31)^{-}\end{array}$ & $\begin{array}{r}17 \\
(47)\end{array}$ & $\begin{array}{r}9 \\
(41)\end{array}$ & $\begin{array}{r}26 \\
(45)\end{array}$ & $\begin{array}{r}3 \\
(30)^{3}\end{array}$ & (8) & (18) \\
\hline & 特定的 & $\begin{array}{r}11 \\
(79)\end{array}$ & $\begin{array}{r}7 \\
(58)\end{array}$ & $\begin{array}{r}18 \\
(69)\end{array}$ & $\begin{array}{r}19 \\
(53)\end{array}$ & $\begin{array}{r}13 \\
(59)\end{array}$ & $\begin{array}{r}32 \\
(55)\end{array}$ & $\begin{array}{r}7 \\
(70)^{7}\end{array}$ & $\begin{array}{r}11 \\
(92)\end{array}$ & $\begin{array}{r}18 \\
(82)\end{array}$ \\
\hline & 計 & $\begin{array}{r}14 \\
(100)\end{array}$ & $\begin{array}{r}12 \\
(100)\end{array}$ & $\begin{array}{r}26 \\
(100)\end{array}$ & $\begin{array}{r}36 \\
(100)\end{array}$ & $\begin{array}{r}22 \\
(100)\end{array}$ & $\begin{array}{r}58 \\
(100)\end{array}$ & $\begin{array}{r}10 \\
(100)\end{array}$ & $\begin{array}{r}12 \\
(100)\end{array}$ & $\begin{array}{r}22 \\
(100)\end{array}$ \\
\hline \multirow{3}{*}{ 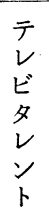 } & 重複的 & $\begin{array}{r}4 \\
(29)\end{array}$ & $\begin{array}{r}3 \\
(25)\end{array}$ & $\begin{array}{r}7 \\
(27)\end{array}$ & $\begin{array}{r}12 \\
(33)\end{array}$ & $\begin{array}{r}8 \\
(36)\end{array}$ & $\begin{array}{r}20 \\
(34)\end{array}$ & $\begin{array}{r}4 \\
(40)\end{array}$ & $\begin{array}{r}2 \\
(17)^{2}\end{array}$ & $\begin{array}{r}6 \\
(27)\end{array}$ \\
\hline & 特定的 & $\begin{array}{r}10 \\
(71)\end{array}$ & $\begin{array}{r}9 \\
(75)^{2}\end{array}$ & $\begin{array}{r}19 \\
(73)\end{array}$ & $\begin{array}{r}24 \\
(67)\end{array}$ & $\begin{array}{r}14 \\
(64)\end{array}$ & $\begin{array}{r}38 \\
(66)\end{array}$ & $\begin{array}{r}6 \\
(60)\end{array}$ & $\begin{array}{r}10 \\
(83)\end{array}$ & $\begin{array}{r}16 \\
(77)\end{array}$ \\
\hline & 計 & $\begin{array}{c}14 \\
(100)\end{array}$ & $\begin{array}{r}12 \\
(100)\end{array}$ & $\begin{array}{r}26 \\
(100)\end{array}$ & $\begin{array}{r}36 \\
(100)\end{array}$ & $\begin{array}{r}22 \\
(100)\end{array}$ & $\begin{array}{r}58 \\
(100)\end{array}$ & $\begin{array}{r}10 \\
(100)\end{array}$ & $\begin{array}{r}12 \\
(100)\end{array}$ & $\begin{array}{r}22 \\
(100)\end{array}$ \\
\hline
\end{tabular}


児童のテレビ行動におけるオビニオン・リーダーシップ

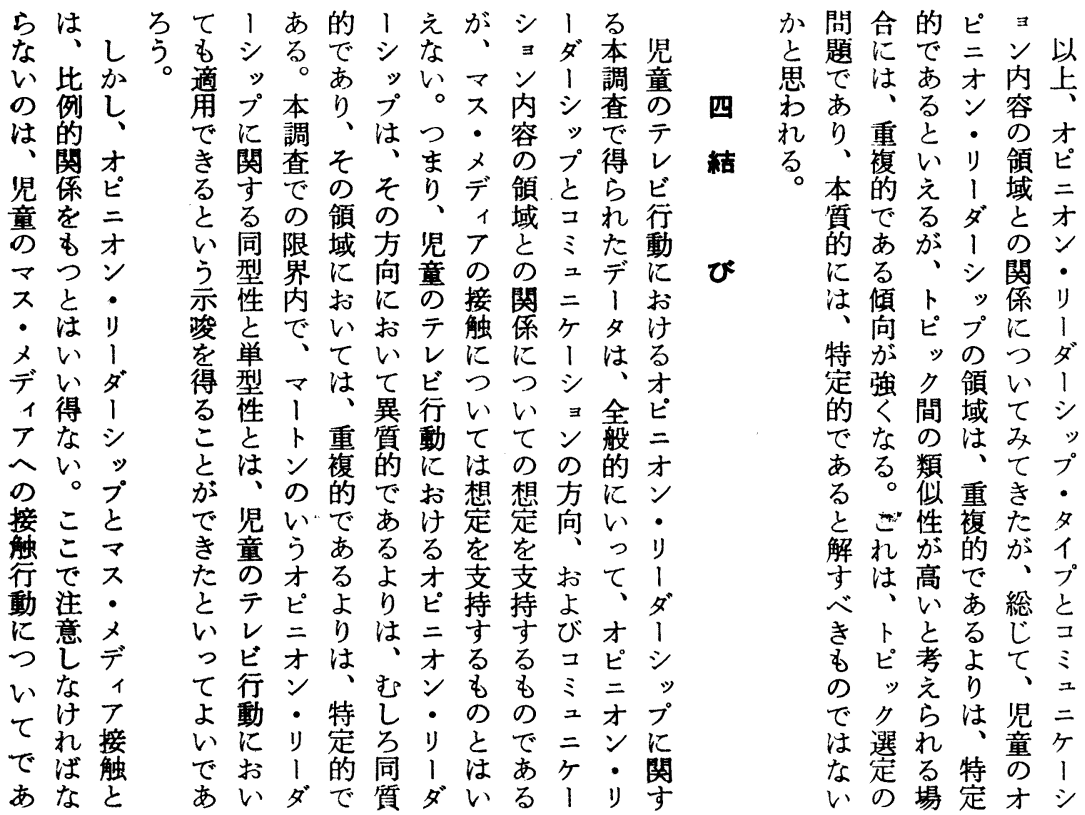

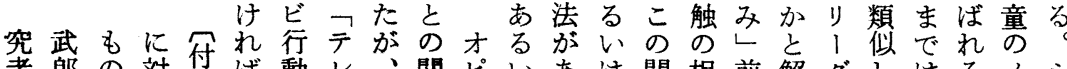
者郎の対記ば動レ、関ピいあ減相前解ダしはるメシ 中教です虍なとビ前係二はろ広題異のす、て小デニ

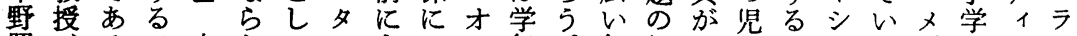
照るる本なてレるつン年。年解よ童こッるデ六アム 海調・レ研いのン指い・に本令明り染とプとィ年接 助查終ビ究でトト摘てリよ調層の強、毛の考了生触之 教デ始ジはあピレしは1る査にたく被で夕え行頃は多 授ザいョ、ろッとた、ダ統でわめ㗢調きイら動を、空

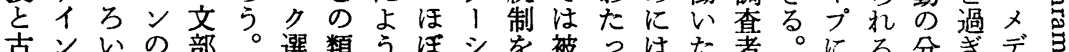

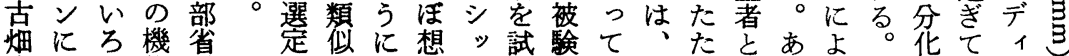
和つと能科 の性、定プみ者調年めさるるこ方、アた 孝いごし学問㤎々しとる数査令でれい相のな使た

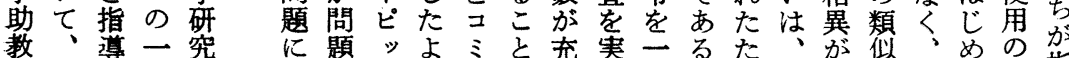

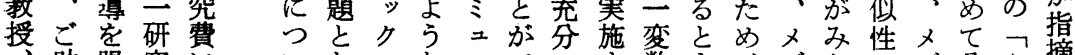

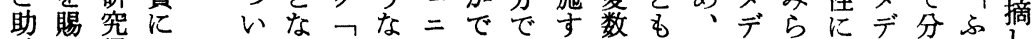
調言わ課よてるテ結ケきなると解年1れよ11化くし 查をっ題る は。レ果はなかなしす令アなってすらて 実いたと機 施た代し関 にだ表て研 多以研行究 大た究なっ の分者わ青 忌然布れ少た年 今しビ音シかっどてるに使かて行るるる 後が鲵るンたたい制之る角ったオにつっよ

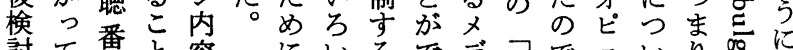

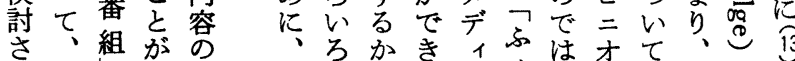

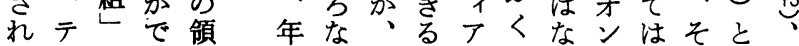
なレとき域令方あ。接らい、、れよ児 

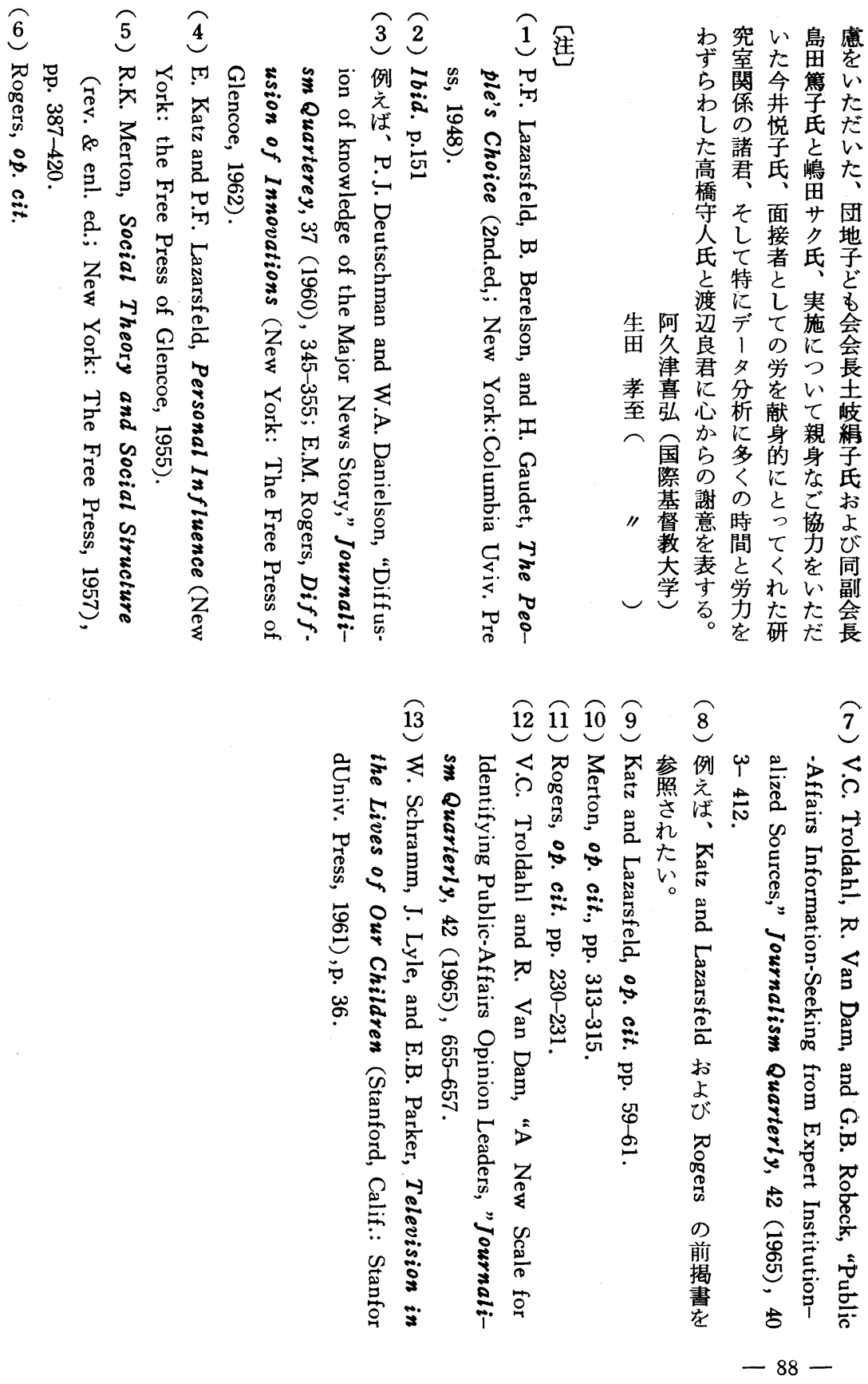
behavior is categorized into the four types: TV-type (high TV and low print); Print-type (low TV and high print); High users (high TV and high print); and Low users (low TV and low print). With the fourth graders, variables which have significant partial correlations with school achievement were intelligence, creativity, positivity and parent-child conflict. With the seventh graders, they were intelligence, adaptability, creativity, social class, and social norm. The partial correlation between school achievement and TV-Print behavior, however, was significant with neither of fourth and seventh graders. We can conclude that the less. achievement of TV-type groups is not due to the direct effects of television, but depends upon the intervening effects of predispositions and/or children's "parent troubles."

\title{
Opinion Leadership in Children's Television Behavior
}

\author{
Yoshihiro Akutsu \& Takashi Ikuta \\ (International Christian University)
}

The purpose of this study is to examine Merton's notions of status homophily and monomorphic type on opinion leadership, that is, to determine the directional and morphic types of opinion leadership in children's television behavior.

The following assumptions are made to attain the purpose:

(1) The directional type of opinion leadership in children's television behavior is homophily rather than heterophily.

(2) There is a positive relationship between opinion leadership in children's television behavior and mass media exposure; that is, the higher is opinion leadership, the higher mass media exposure.

(3) The morphic type of opinion leadership in children's television behavior is monomorphic rather than polymorphic.

\section{METHOD}

Subjects. Children who dwelt at O-danchi in Sagamihara city and who were third graders through sixth graders during the survey period of 
March 7 and 8, 1970, comprise the subjects in this study with the resultant total number of 226.

Measurement of Opinion Leadership. A four-item self-designating opinion leadership scale was developed, using the items from Rogers' six-item cpinion leadership scale and Troldahl's seven-item scale for identifying opinion leaders.

Measurement of Mass Media Exposure. (1) Television-viewing, by the number of television programs viewed regularly during a week; (2) Radiolistening, by the frequency of radio listening during a week; (3) Newspaperreading, by the frequency of newspaper reading during a week; (4) Magazine-reading, by the number of magazines read during a week; and (5) Movie-going, by the frequency of movie going during a term.

The directional Type of Opinion Leadership. A subject was asked to tell an interviewer with whom he most often discussed each of the three topics used in this study (television programs, television talents, and color television sets). If his discussants are his peers, the directional type is defined as homophily. If his discussants are his family members or his school teachers, the type is defined as heterophily.

The Morphic Type of Opinion Leadership. If a subject has the opinion deadership pattern only on a single topic, his morphic type is defined as monomorphic. If he has the same opinion leadership pattern on the two topiçs, his type is defined as polymorphic.

Data Gathering. The individual interview was used. A subject was interviewed by a staff member or a graduate student of International Christian I'niversity at the subject's home.

\section{RESULTS}

The entire pattern of the data supports the assumptions on the directional and morphic types of opinion leadership, but does not support the assumption on mass media exposure. 